\title{
The forecast of biogas production from rice straw to cover the energy demand for a rice mill
}

ABSTRACT: In literature as well as in the university debate, we can observe the increase of interest regarding converting agricultural residues into energy. Furthermore, the energy and climate policies have encouraged the development of biogas plants for energy production. One of the most significant reasons of this escalation is that this technology may be both convenient and beneficial. The produced biogas is not only supposed to cover the energy demand like heat and electricity, the resulting digestate has the prospect of a beneficial fertilizer and can thereby influence the energy management plans. This technology is widely introduced to countries, which have large income from agriculture. Not only does this reduce the use of industrial fertilizers, but also finds use for agricultural residues. One of the countries of this type is Vietnam, which is the fifth largest exporter of rice in the world. Over 55\% of greenhouse gas emission in Vietnam comes from agriculture. Using innovative technologies such as biogas, may decrease this value in near future. It may also contribute to more sustainable agriculture by decreasing traditional fields burning after the harvesting period. The goal of this research paper is to estimate the possible production of biogas from rice straw to cover the energy demand of the rice mill. Four possible scenarios have been considered in this paper, the present situation and where electricity, energy or both were covered by biogas from agricultural residues. An attempt was made to answer the question whether the amount of biogas produced from agricultural residues is enough for both: electricity and energy supply, for the rice mill. If not, how much rice straw must be delivered from other sources, from which rice is not delivered to the rice mill. The base of the assumptions during the estimation of various values were statistics from FAO and other organizations, secondary sources and data from the existing rice mill in Hậu Mỹ Bắc B in Mekong delta in Vietnam.

KEYWORDS: biogas, agricultural residues, energy demand

\footnotetext{
${ }^{1}$ Technische Universität Berlin, ORCID: 0000-0002-4091-4363.
} 


\section{Introduction}

Vietnam has become a middle-income country since the economic reform, especially in the agriculture sector. According to the reports published by the Food and Agriculture Organization of the United Nations (2017), the country is the worlds' $27^{\text {th }}$ largest emitter of greenhouse gases and it contributes around $0.72 \%$ to total global emission. Vietnam is also the $5^{\text {th }}$ word largest exporter of rice and the biggest source of methane is brought by rice cultivation (FAO 2017).

In of the past several years, rapid growth in the industry sector and social and economic development in the country has led to growing energy consumption. An increased dependency on fossil fuels goes hand in hand with its continuous growth. Regarding energy, it is worth mentioning that the total primary energy consumption in Vietnam has strongly depended on biomass (wood, agricultural residues). The share of biomass energy accounts for more than one third of the total energy consumption during the last decade. This non-commercialized energy is traditionally used in rural areas, and $80 \%$ of households in rural areas have used biomass for cooking and heating. Traditional use of biomass is ineffective in terms of energy and harmful to the environment and human health. Extra amounts of waste biomass also create environmental pollution in some regions where intensive agricultural activities occur (Diep et al. 2015).

Small to medium scale biogas plants that are installed in households and are operated by locals tend to be the non-commercialized energy sources. This leads to constant misuses and deviations in operation, which consequently leads to leakages of methane, which causes greater environmental chaos than untreated waste. Another factor that causes the lack of interest in biogas production technology is the deficit of household appliances that can be operated through biogas. So that biogas production is only seen as a waste management option and not as a secondary source of energy. Therefore, it is critical to provide an extensive, clear, coherent and unambiguous training program. It is indispensable for such a training degree to be enforced through policies and standards, as a corrective and preventive measure.

Each year the rice cultivation produces 1,4 trillion tons of agricultural waste (Darmawan et al. 2018). This so-called agricultural waste has a high potential to become an energy and nutrient source. Agricultural residues from rice production are separated in husks and rice straw. So far, husks are used for the drying processes and rice straw mostly remain on the field and are burned. Dangerous uncontrolled fires in hot climates and harmful smoke developments are among the disadvantages of this solution.

Current technological progress keeps focusing on waste streams to discover an alternative energy and nutrient sources. The energy management plan of the selected rice production process has focused on using agricultural residues to cover its own energy demand. Therefore, the supply by a biogas plant was investigated. Nevertheless, the results of this research paper mainly contain the estimation of possible biogas productions to cover the energy demand of the rice mill. Four different scenarios were proposed, which consider biogas production for electricity or heat separately, for both electricity and heat, or no production of biogas at all. The calculations 
were made, to answer the question, whether the amount of biogas is enough for both energy demands: which are the heat and electricity supply for the rice mill. If not, how much rice straw is still needed and must be delivered from neighbor rice plantations.

\section{Motivation and methods}

The main aim is to discover a possible self-sufficiency by creating an energy and material cycle. The reducing dependence of public electricity supply and external industrial fertilizers are auspiciously advantageous. Also, through the self-sufficiency by converting agricultural residues, greenhouse gas emissions can be cut down. Through this project, designing an energy management plan for a rice husk fermentation plant in Hậu Mỹ Bắc B (HMBB) was intended. This was to be achieved by taking various factors into account, such as physical limitations that can interfere with our rice husk storage and by-products. The designed plant will provide a panoramic approach to guarantee energy security for industrial users, as well as to diversify energy provision. This report will also quantify materials and energy flows and explain the assumptions and calculations briefly.

Several methods were used during the data collecting process. The research was focused on the case study of the rice mill in Hậu Mỹ Bắc B located in Vietnam. Before preparing the paper, the questionnaire was sent to estimate the energy demand as well as the amount of processed rice. This is composed of four parts. The first part includes questions regarding the rice production process which allows the maximum possible amount of rice straw that could be collected to be estimated. The biogas will be produced only from rice straw. Therefore, the questionnaire also asked for the amount of rice straw from nearby neighborhoods. It should be noted that possible pollutions caused by transport can occur and must be prevented to minimalize additional expenses. The first part of the questionnaire also included questions about rice husk amounts, to estimate a possible profit from selling it.

The second and the third part concerns the energy supply of the rice mill. It includes information about the working time of the rice mill. The questionnaire was also used to estimate the lengths and frequency of the energy cuts. The questionnaire also contains questions regarding the energy demand of each machine and their operating times. Other questions concern the energy demand of the drying and other minor processes. All of the above questions were asked to estimate an average hourly energy demand of the rice mill.

The last part focuses on the fertilizer demand for local farmers. During the biogas production process, the side product - digestate occurs and may be used as a bio fertilizer. Giving it for free to the local farmers may contribute to gaining a better understanding of sustainable agriculture.

The estimation was based mostly on an analysis of secondary sources, such as academic publications. The literature research was overtaken, to estimate crucial values such as the amount of biogas produced out of one ton of rice straw, or the heating value of rice husk. Reliable publi- 
cations were taken under consideration during the research period. Other secondary sources included the data published by national and international organizations, such as the United Nations Food and Agriculture Organization, specific subsector information from business and technical journals, other reports and statistics.

Various other methods were used during the knowledge processing. First the assessment of energy demand and prices in the study region were made. This was based on the questionnaire answers, given from the rice mill. Afterwards, the energy and mass balance calculations for the baseline situation and biogas production were preceded, based on a developed calculation model. Thereafter the tendencies were identified by developing the indicators. Analysis and comparison methods were used to find the most suitable solution.

During the calculations it was assumed that the rice straw is delivered only from rice fields, from which rice is also delivered. This simplification was made to avoid possible considerations of the logistic model. In Hậu Mỹ Bắc B, most of the roads are passable only by pedestrians, or very small mechanical vehicles. Furthermore, not all canals, which also have a logistic purpose, are suitable to transport rice or rice straw from fields. It is also more likely that the customers of a rice mill will be more willing to sell their rice straw or accept a biofertilizer.

\section{Calculation model}

To estimate the amount of biogas, the calculation model based on secondary sources was used. To simplify the forecast, both the electricity demand and biogas production was adjusted daily. This was possible, because according to the questionnaire, rice is delivered to the rice mill daily. There was also no exact time of crops collection. However, they are usually collected three times a year in various dates for each farm.

Firstly, the estimation of rice straw input $\left(\mathrm{S}_{\text {in }}\right)$ was made. Based on the information from the questionnaire, it was known that around 15\% of all rice is delivered from Hậu Mỹ Bắc B. This does not mean that other rice straw cannot be collected from other neighborhood areas, however this value was taken for the first estimates There is around 1.05 kilograms of rice straw. For one kilogram of rice (Darmawan et al. 2018). The amount of rice straw from Hậu Mỹ Bắc B was estimated by this analogy.

$$
S_{\text {in }}=\left(R_{\text {in }} \cdot 15 \%\right) \cdot 1,05[\mathrm{~kg} / \mathrm{day}]
$$

In the second step, the average biogas production from rice straw was estimated. The forecast was based on the proportion of $300-400 \mathrm{~m}^{3}$ of biogas, from each ton of rice straw (Nguyen 2011). For the calculation model, the average value of $0,35 \mathrm{~m}^{3}$ of biogas, from each kilogram of rice straw was used. 


$$
B_{\text {out }}=S_{\text {in }} \cdot 0,35[\mathrm{~kg} / \mathrm{day}]
$$

Two kinds of energy demands were used for the purpose of calculation model : the heat for dryers and the electricity for other machines in the rice mill. The calorific value of biogas, which contains around $50-55 \%$ of methane, is estimated in literature at $21.6 \mathrm{MJ} / \mathrm{m}^{3}$ (FNR 2006).

$$
H_{B}=B_{\text {out }} \cdot 21,6[\mathrm{MJ} / \mathrm{day}]
$$

The amount of $\mathrm{kWh}$ produced out of $1 \mathrm{~m}^{3}$ of biogas is estimated in the literature at 1.5$3 \mathrm{kWh}$ (FNR 2009). For calculation purpose, the average value has been used, which is 2.25 $\mathrm{kW} / \mathrm{m}^{3}$.

$$
E l_{B}=B_{\text {out }} \cdot 2,25[\mathrm{~kW} / \text { day }]
$$

Based on values calculated above, it was possible to foresee the heat and electricity production from delivered rice straw for different scenarios.

The last step of the calculations was a prognosis for produced fertilizer. The side product digestate is produced during production of biogas. It has a high value of nutrients, so it may be used as a bio fertilizer. To calculate output, first the input has to be estimated. The optimal water content of input should be around $90 \%$ (Christensen 2010). The average water content of rice straw is $10 \%$ (Zhang et al. 2012), therefore, water has to be added $\left(\mathrm{x}_{\mathrm{W}+}\right)$ :

$$
x_{w^{+}}=x_{D} \cdot 90 \%-S_{i n} \cdot 10 \%
$$

Total inut can be calculated as a sum of rice straw and added water. After the correct process of digestion, around $8 \%$ of total input becomes a biogas, and around $92 \%$ a digestate (Christensen 2010). After removing the remaining water, dry digestate is received, which can be used as a fertilizer. The water is treated and added again to the process.

\section{Scenarios}

Before the calculation and estimation of biogas production, 4 various scenarios were considered. They can be seen in the Table 1 . 
TABLE 1. Possible scenarios

TABELA 1. Rozpatrywane scenariusze

\begin{tabular}{|c|c|c|}
\hline No. of scenario & Heating demand & Electricity demand \\
\hline 1 & Rice husk & Local provider \\
\hline 2 & Rice husk & Biogas \\
\hline 3 & Biogas & Local provider \\
\hline 4 & Biogas & Biogas \\
\hline
\end{tabular}

Source: own calculations.

The first scenario describes a situation without biogas installation. The rice husk is sold or burned for drying rice in dryers. The electricity demand is covered with electricity from the grid. The strength of this scenario is that it is already well known by the owner of the rice mill and does not require any financial changes. However, there are various weaknesses. Around once a month there is an energy cut which makes it impossible to process rice for around 12 hours. The electricity source is not only unreliable, but also not environmentally friendly. According to International Energy Agency (2015) over 60\% of electricity is generated by fossil fuels such as gas, coal or oil. It highly contributes to the increase of air pollution in the region. Furthermore, the first scenario does not solve the problem of the management of agricultural residues such as rice straw that is usually burned on the field, to fertilize the ground. Unfortunately, fire is impossible to control and may lead to local fires. They are also excessively dangerous for insects and other lifeforms.

The second scenario replaces electricity from the grid with generating electricity from biogas. In this case the impact was put on turning into a more reliable electricity source, which may be generated by the owner of the rice mill. However, the efficiency of converting biogas into electricity is relatively low. It does not exceed $40 \%$. In the third scenario, the focus was put on efficiency. Biogas is used only to dry rice and replace rice husk, which may be sold. The electricity source is, as in the first scenario, the local energy provider. The last, forth scenario combines both: the second and third. The mentioned rice mill would be independent from electricity cuts and may sell all unused rice husks, to gain higher economic benefits.

\section{Outcome}

According to calculated values of electricity and heat demand, scenarios 2, 3 and 4 were considered. Before calculations, the amount of $7 \%$ of biogas was deducted, for sustaining the biogas installation according to data from project partner Herbst Umwelttechnik. 
The second scenario, where the impact was put on fulfilling the electricity demand of the rice mill, can be achieved by collecting rice straw just from the rice fields in HMBB, from which rice was delivered. According to the forecasted estimations, the electricity demand for the rice mill is $1382.7 \mathrm{kWh}$, and the maximum estimated electricity production is $1369.8 \mathrm{kWh}$. The difference between both values is below $1 \%$, therefore the margin of error is within an acceptable range. Apart from the range of benefits obtained by using biogas technology, the strong advantage of this scenario, is that the rice mill becomes $100 \%$ independent of electricity cuts.

The third scenario, which firstly considered covering energy demand for drying purpose, can also be achieved by collecting rice straw just from the rice fields in HMBB, from which rice was delivered. As Table 3 shows, the amount of heat is covered and some biogas is still left.

TABLE 2. Amount of heat and electricity produced from rice straw from HMBB for the $3^{\text {rd }}$ scenario

TABELA 2. Ilość ciepła i energii elektrycznej wyprodukowanej ze słomy ryżowej z HMBB dla trzeciego scenariusza

\begin{tabular}{|c|c|c|}
\hline Desired heat $(\mathrm{H}):$ & 7200 & $\mathrm{MJ} / \mathrm{h}$ \\
\hline Extra heat: & 6939.6 & $\mathrm{MJ} / \mathrm{h}$ \\
\hline Biogas left: & 321.3 & $\mathrm{~m} / \mathrm{h}$ \\
\hline Electricity: & 722.9 & $\mathrm{kWh} / \mathrm{h}$ \\
\hline
\end{tabular}

Source: own calculations.

It may be used for electricity cuts, which are known to take place around 48 hours before. It may also be a good opportunity to develop a rice mill infrastructure. According to the received questionnaire answers, there are plans to purchase another 20 dryers.

However, it is impossible to cover energy demand for the rice mill only with the straw which is delivered from the rice fields in HMBB, from which rice was collected. Additionally, it is very significant for the Vietnam case that villages are not as separate as for example in Europe. The villages are usually rectangle formed areas, which can be found along the road. In this particular case Hậu Mỹ Bắc B is on the north of road DT865, and Hậu Mỹ Bắc A can be found on the south. The rice mill is situated next to the road; therefore, it is possible to deliver rice straw from both villages.

It is also possible to collect rice straw from the other closest areas, for example from Hậu Mỹ Bắc A or other rice fields in Hậu Mỹ Bắc B after developing a suitable logistic concept. To calculate how much biogas is needed in total, the calculation of biogas used to fulfil the electricity demand was made.

$$
B_{E}=\frac{\left(E_{D}+E_{B}\right)}{2,25}
$$

It is simply the opposite of equation 3.4. The achieved values can be found in Table 3 . 
TABLE 3. Amount of biogas used for electricity production

TABELA 3. Ilość biogazu wykorzystywanego do produkcji energii elektrycznej

\begin{tabular}{|l|c|c|c|}
\hline Desired Electricity: & $\mathrm{E}_{\mathrm{D}}$ & 1557,9 & $\mathrm{~kW} / \mathrm{h}$ \\
\hline Desired Electricity for biogas plant: & $\mathrm{E}_{\mathrm{B}}$ & 175.2 & $\mathrm{~kW} / \mathrm{h}$ \\
\hline Biogas used for electricity demand: & $\mathrm{B}_{\mathrm{E}}$ & 770,3 & $\mathrm{~m}^{3} / \mathrm{h}$ \\
\hline
\end{tabular}

Source: own calculations.

A further equation was used to calculate the possible biogas amount to cover the heat demand:

$$
B_{H}=\frac{H_{D}}{21,6}
$$

This is the opposite of equation 3.3. The achieved values can be found in Table 4 .

TABLE 4. Amount of biogas used for electricity production

TABELA 4. Ilość biogazu wykorzystywanego do produkcji ciepla

\begin{tabular}{|l|c|c|c|}
\hline Desired Heat: & $\mathrm{H}_{\mathrm{D}}$ & 7200 & $\mathrm{MJ} / \mathrm{h}$ \\
\hline Biogas used: & $\mathrm{B}_{\mathrm{H}}$ & 333,3 & $\mathrm{~m}^{3} / \mathrm{h}$ \\
\hline
\end{tabular}

Source: own calculations.

To cover both the heat and electricity demand, around $1100 \mathrm{~m}^{3}$ of biogas must be collected every hour. For that the calculation model had to be edited. To supply this energy requirement, the amount of rice straw delivered to the rice mill should be increased by almost $70 \%$, from 45 to 75 tons daily. It is highly possible, because the area of both HMBA and HMBB are almost $80 \%$ covered by rice fields. However, the logistic concept for the delivery of rice straw have to be designed.

\section{Discussion and conclusions}

This paper aimed to analyze the performance of possible biogas plant located in the Mekong delta in Vietnam. A scenario analysis was carried out based on a calculation model to identify the possible production of biogas out of agricultural residues. It is possible to cover the full demand for electricity or the full demand for heat and a part of electricity with biogas produced from rice straw just from the rice fields in HMBB, from which rice was delivered. After extending the rice 
straw collecting area, it is possible to meet the demand for both heat and electricity. However, for this purpose the logistic model must be developed in the future. Nevertheless, it was proved that by using the biogas technology, the rice mill may be independent from energy delivery from third parties.

The remaining digestate can be given to farmers to reduce the use of chemical fertilizers and contribute to more sustainable rice cultivation. It may also be offered only for farmers who agree to sell rice straw for biogas production. A high percentage of farmers prefer to burn the residues in order to fertilize the ground rather than sell it, mostly because it requires letting in heavy machines on the field.

The most important outcome of this research is that there are alternative solutions to solve existing problems related to intensive rice cultivation, such as agricultural waste management, waste valorization and energy independence, as well as the safety for industrial users. It also provides a panoramic view for local farmers associations of the fact-based decision making. Nevertheless, the implementation of this environmentally friendly technique depends widely on a political framework that creates and provides an economically attractive incentive for running plants. One remaining question is whether the examined options are well accepted among future investors and local decision makers.

\section{References}

CHRISTENSEN, T. 2010. Solid waste technology and management. Blackwell Publishing Ltd, New Jersey.

DANG et al. 2019 - DANG, T.T., SAITO, O., YAMAмOTO, Y. and TOKAI, A. 2010. Scenarios for Sustainable Biomass Use in the Mekong Delta, Vietnam. Journal of Sustainable Energy and Environment vol. 1(3), pp. 137-148.

Darmawan et al. 2018 - Darmawan, A., Fitriano, A.C., Aziz, M. and ToKimatsu, K. 2018. Integrated system of rice production and electricity generation. Applied Energy vol. 220, pp. 672-680.

DieP et al. 2015 - DieP, N.Q., SAKAnishi, K., NAKagoshi, N., Fujimoto, S. and Minowa, T. 2015. Potential for rice straw ethanol production in the Mekong Delta, Vietnam. Renewable Energy vol. 74, pp. 456-463.

Do, N.Q. 1989. Experience on organizing and deploy the biogas plant at provinces in the Mekong Delta The first step in Can Tho city. National Renewable Energy Program 52C, Ho Chi Minh.

FNR 2006 - Fachagentur Nachwachsende Rohstoffe e.V. (FNR), 2006. Handbook of biogas production and utilization (Handreichung Biogasgewinnung und - nutzung), Berlin (in German).

FNR 2009 - Fachagentur Nachwachsende Rohstoffe e.V., (FNR) 2009. Biogas Basisdaten Deutschland Stand: Oktober 2008. 7 p. Very short but comprehensive overview of the biogas situation in Germany, Berlin.

FAO 2017 - Food and Agriculture Organization of the United Nations (FAO), 2017. Country Programming Framework for Viet Nam: 2017-2021, Hanoi.

KAPUR et al. 1994 - KAPUR, T., KANDPAL, T.C. and GARG, H.P. 1994. An optimization model for energy supply to rice mills in India. International J. of Energy Research vol. 21(4), pp. 341-358.

Kargbo et Al. 2010 - Kargbo, F., Xing, J. Zahang, Y. 2010. Property analysis and pretreatment of rice straw for energy use in grain drying: A review. Agriculture and biology journal of North America. 
Krich et al. 2005 - Krich, K., Augenstein, D., Batmal, J.P., Benemann, J., Rutledge, B. and SAlOUR, D. 2005. Biomethane from Dairy Waste: A Sourcebook for the Production and Use of Renewable Natural Gas in California, USD Rural Development. Washington.

Mansaray, K.G. and GHAlY, A.E. 1996. Physical and thermochemical properties of rice husk. Energy sources vol. 19, pp. 989-1004.

NGUYEN, G.L. and NGUYeN, Q.K. 2005. Development of biogas technology in Vietnam. Journal of Vietnamese Environment vol. 1(1), pp. 12-18.

Nguyen et al. 2012 - Nguyen, T.T., Bie, C.D., Ali, A., Smaling, E. and ChU, T.H. 2012. Mapping the irrigated rice cropping patterns of the Mekong delta, Vietnam, through hyper-temporal SPOT NDVI image analysis. Journal of remote sensing 33(2), pp. 415-434.

NGUYEN, V.C. 2011. Small-scale anaerobic digesters in Vietnam - development and challenges. Journal of Vietnamese Environment vol. 1(1), pp. 12-18.

SHEN et al. 2012 - SHEN, J., ZHU, S., LIU, X., ZHANG, H. and TAN, J. 2012. Measurement of Heating Value of Rice Huskby Using Oxygen Bomb Calorimeter with Benzoic Acid as Combustion Adjuvant. Energy Procedia vol. 17, pp. 208-213.

Vu et al. 2015 - Vu, T., Vu, D.Q., JENSE, L.S., SOMmER, S.G. and BRUUn, S. 2015. Life Cycle Assessment of Biogas Production in Small-scale Household Digesters in Vietnam. Asian-australasian Journal of Animal Sciences vol. 28(5), pp. 716-729.

YUAN, S. and PENG, S. 2017. Input-output energy analysis of rice production in different crop management practices in central China. Energy vol. 141, pp. 1124-1132.

ZAFAR, S. 2015. Biomass Resources from Rice Industry. [Online] https://www.bioenergyconsult.com/tag/ energy-potential-of-rice-husk/ [Accessed 2018-11-05].

ZEEUw, D.W. and LeTtingA, G. 1983. Biogas generation and anaerobic treatment of waste water in Vietnam. [Online] http://library.wur.nl/webquery/wurpubs/76895 [Accessed 2018-11-05].

ZHANG, Q. et al. 2017. Stimulatory effect of in-situ detoxification on bioethanol production by rice straw. Energy vol. 135, pp. 32-39.

\section{Prognoza produkcji biogazu ze słomy ryżowej w celu pokrycia zapotrzebowania na energię dla młyna ryżowego}

\section{Streszczenie}

W literaturze, jak również w debacie uniwersyteckiej, obserwujemy wzrost zainteresowania przekształcaniem odpadów rolniczych w energię. Ponadto polityka energetyczna i klimatyczna zachęciły do rozwoju produkcji biogazu do celów energetycznych. Jedną z najważniejszych przyczyn tej eskalacji jest to, że technologia ta może być zarówno wygodna, jak i korzystna. Wytworzony biogaz nie tylko może pokryć zapotrzebowanie na energię, jak ciepło i elektryczność, ale otrzymany poferment ma perspektywę korzystnego nawozu, a tym samym może wpływać na plany zarządzania energią. Technologia ta jest szeroko 
stosowana w krajach, które mają duże dochody z rolnictwa. Nie tylko zmniejsza stosowanie nawozów przemysłowych, ale także znajduje zastosowanie w przypadku pozostałości rolniczych. Jednym z takich krajów jest Wietnam, który jest piątym największym eksporterem ryżu na świecie. Ponad 55\% emisji gazów cieplarnianych w Wietnamie pochodzi z rolnictwa. Korzystanie z innowacyjnych technologii, takich jak biogaz, może zmniejszyć tę wartość w najbliższej przyszłości. Może również przyczynić się do bardziej zrównoważonego rolnictwa, poprzez zmniejszenie tradycyjnego spalania odpadów rolniczych po okresie zbiorów. Celem tego artykułu badawczego jest oszacowanie możliwej produkcji biogazu ze słomy ryżowej, aby pokryć zapotrzebowanie na energię młyna ryżowego. W niniejszym dokumencie rozważono cztery możliwe scenariusze, obecną sytuację oraz hipotetyczne tezy, w których energia elektryczna, ciepło lub obie formy energii zostały pokryte z biogazowni. Podjęto próbę odpowiedzi na pytanie, czy dla młyna ryżowego ilość biogazu wytworzonego z odpadów rolniczych jest wystarczająca zarówno dla energii elektrycznej, jak i dla ciepła. Jeśli nie, to jaka ilość słomy ryżowej musi być dostarczona z innych źrodeł, z których ryż nie jest dostarczany do młyna. Podstawą założeń przy szacowaniu różnych wartości były statystyki z FAO i innych organizacji, źródła wtórne i dane z istniejącego młyna ryżu w Hậu Mỹ Bắc B w delcie Mekongu w Wietnamie.

SŁoWA KLUCZOWE: biogaz, odpady rolne, zapotrzebowanie na energię, słoma ryżowa 
